\title{
Effects of domestication related genes on behaviour, physiology and gene expression in chickens
}

\author{
Anna-Carin Karlsson
}

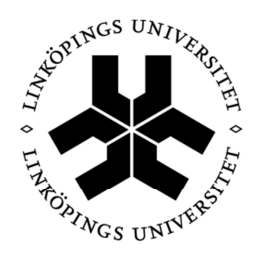

\section{Linköping University INSTITUTE OF TECHNOLOGY}

\author{
IFM Biology
}

AVIAN Behavioural Genomics and Physiology Group

Linköping University, SE-58183 Linköping, Sweden

Linköping 2014 
Effects of domestication related genes on behaviour, physiology and gene expression in chickens

Linköping Studies in Science and Technology

Dissertation No. 1633

ISBN 978-91-7519-184-3

ISSN 0345-7524

Front cover: White Leghorn male and females

Photo: Anna-Carin Karlsson

Copyright $\odot 2014$ Anna-Carin Karlsson unless otherwise noted

Printed by LiU-Tryck, Linköping 2014 
Till minnet av min älskade vän.

I tanken, i skrattet, i hjärtat. För alltid. 

Domestication, the process when animals adapt to captivity, tends to modify a whole array of traits towards what has been termed "the domesticated phenotype", where the domesticated animal differs from its wild ancestor in morphology, physiology, development and behaviour. Physiological traits and behaviours are controlled by genes. One single gene can control several different traits (pleiotropy), be linked to a neighbouring gene on the chromosome, or interact with another gene that in turn controls another trait. This is the explanation why one can select for high egg production and at the same time get a change in the colour of the plumage. The aim of this thesis was to evaluate the effect of a mutation in two particular genes (PMEL17 and TSHR) related to domestication on behaviour, gene expression and other physiologial traits. The animals investigated were chickens from a cross between the ancestral Red Junglefowl (RJF) and the domesticated White Leghorn (WL) selected for high egg production traits. PMEL17 is a gene affecting plumage colour. A mutation in the gene causes a non-pigmented white plumage and has been shown to protect against feather pecking. Our studies showed that a mutation in the PMEL17 gene affects social, explorative and aggressive behaviour in chickens, but not visual ability. The thyroid stimulating hormone receptor (TSHR) plays an important role in the signal transduction of the hypothalamus-pituitary-thyroid axis that has general effects on development, behaviour and reproduction. A mutation in the TSHR gene affects incubation time, domestication related behaviours such as fear and aggression, gene expression, thyroid hormone levels and photoperiodic reproduction responses in chicken. The results from this thesis suggest that a mutation in the PMEL17 and TSHR genes have pleiotropic effects on behaviour and traits related to domestication, and it is therefore likely that both genes have been important for the domestication of the chicken. 



\section{Populärvetenskaplig sammanfattning}

För cirka 8000 år sedan började vi människor att avla vilda höns för egenskaper som gynnar oss. Exempel på dessa egenskaper är hög äggproduktion och stor muskelmassa för köttproduktion. Att aktivt välja ut och avla på de individer som lägger flest ägg och uppvisar snabbast tillväxthastighet gör att djuren förändras. Denna förändringsprocess kallas domesticering.

Domesticeringen innebär inte bara att vissa utvalda egenskaper ändras, utan den bidrar också till förändringar i beteende och utseende, dvs. djurets fenotyp förändras. Den röda djungelhönan (RJF) anses vara stamfadern till alla dagens hönsraser och lever än idag vilt i Sydostasien. Den har en mörk fjäderdräkt som skiftar i brunt, guld och grönt, väger knappt ett kilo, lever i små grupper, lägger cirka 10 ägg per säsong och är mycket skygg av sig. Den domesticerade hönan som vi ser ute i produktionen har oftast helt vit fjäderdräkt, väger minst dubbelt så mycket som sin förfader, klarar av att leva i stora grupper med tusentals andra individer och är vana vid människor. Domesticeringen har alltså inte bara bidragit till att värphöns idag lägger över 200 ägg per år och att slaktkycklingar mer än tiodubblat sin tillväxthastighet, utan har också orsakat andra fenotypiska förändringar.

Gener kontrollerar både utseende och beteende. En och samma gen kan kontrollera flera olika egenskaper (pleiotropi), eller vara kopplad och samverka med en annan gen som styr en annan egenskap, och därmed föra med sig oanade egenskaper. Detta är förklaringen till att man kan avla för hög äggproduktion och samtidigt få en förändring av till exempel färgen på fjäderdräkten.

Den här avhandlingen fokuserar på två specifika gener, där en mutation i respektive gen har återfunnits hos domesticerade höns men inte hos RJF. Den första genen heter PMEL17 och en mutation i denna ger upphov till en vit, opigmenterad fjäderdräkt som återfinns hos värphöns av typen White Leghorn (WL). Samma mutation har också påvisats skydda mot fjäderhackning. Den andra genen heter TSHR och är en viktig länk för utsöndring av tyroideahormoner, vilka är kända för att ha generella effekter på 
reproduktion, beteende och fysiologiska egenskaper. I denna avhandling undersöks hur en mutation i respektive gen påverkar fenotypen hos höns från en korsning mellan RJF och WL. Resultaten visar att PMEL17-mutationen har en pleiotropisk effekt på socialt, explorativt och aggressivt beteende hos höns, där höns med mutationen bland annat är mindre aggressiva. En mutation i TSHR-genen påverkar utveckling, beteende och tyroidhormon-nivåer, samt djurets reproduktionssystem då dagslängden ändras. De höns med en mutation i TSHR-genen uppvisar liknande beteenden och fysiologisk respons som rena WL.

Resultaten från denna avhandling visar att en mutation i generna PMEL17 och TSHR troligtvis har bidragit till de förändrade egenskaper vi ser hos dagens domesticerade höns då vi jämför dem med den röda djungelhönan. Studierna påvisar dessutom den komplexa koppling som finns mellan enskilda gener och de fenotyper som uppkommer då vi avlar för specifika egenskaper. 


\section{List of publications}

This thesis is based on the following papers, which will be referred to in the text by their Roman numerals (I-V).

Paper I Karlsson, A-C., Kerje, S., Andersson, L., Jensen, P., 2010. Genotype at the PMEL17 locus affects social and explorative behaviour in chickens. British Poultry Science 51, 170-177.

Paper II Karlsson, A-C., Mormede, P., Kerje, S., Jensen, P., 2011. Genotype on the pigmentation regulating PMEL17 gene affects behaviour in chickens raised without physical contact with conspecifics. Behaviour Genetics 41, 312-322.

Paper III Karlsson, A-C., Kerje, S. Hallböök, F. Jensen, P., 2009. The Dominant white mutation in the PMEL17 gene does not cause visual impairment in chickens. Veterinary Ophthalmology 12, 292-298.

Paper IV Karlsson, A-C., Svemer, F., Eriksson, J., Darras, V. M., Andersson, L., Jensen, P., 2014. The effect of a mutation in the thyroid stimulating hormone receptor (TSHR) on development, behaviour and TH levels in domesticated chickens. Submitted manuscript.

Paper V Karlsson, A-C., Fallahshahroudi, A., Johnsen, H., Hagenblad, J., Wright, D., Jensen, P., 2014. The effect of a domestication related mutation in the thyroid stimulating hormone receptor (TSHR) on photoperiodic response and reproduction in chicken. Manuscript. 



\section{Table of contents}

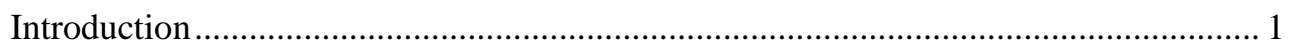

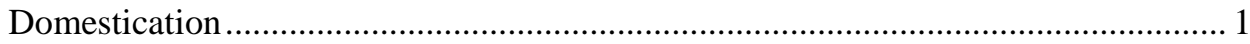

The domesticated phenotype ........................................................................... 2

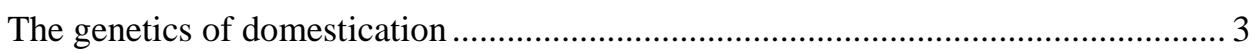

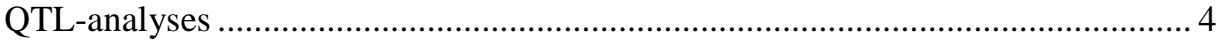

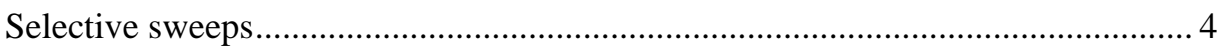

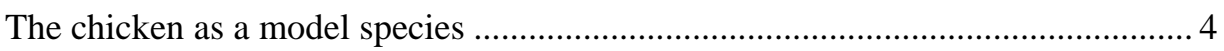

The Locus controlled Advanced Intercross Line .................................................... 6

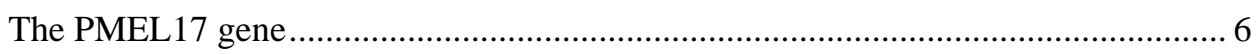

Coat colour and domestication......................................................................... 7

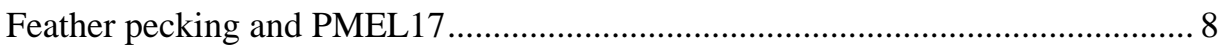

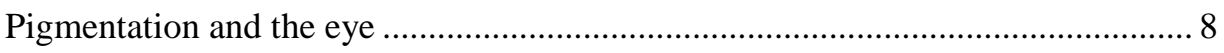

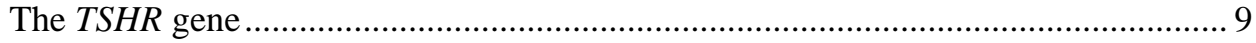

The hypothalamus-pituitary-thyroid axis ......................................................... 9

TSHR and the control of seasonal reproduction.................................................. 10

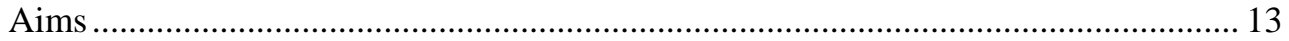

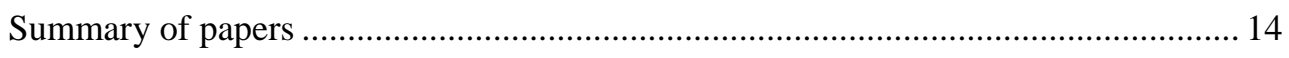

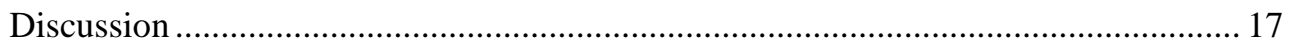

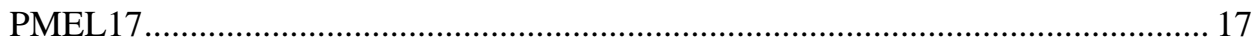

TSHR

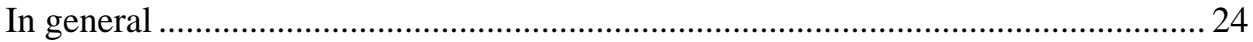

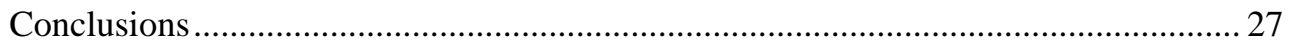

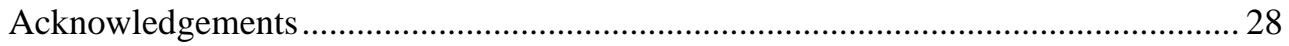

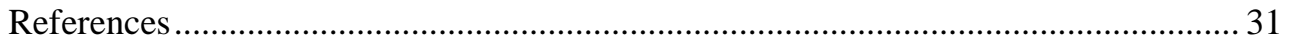





\section{Introduction}

\section{Domestication}

Domestication, the process whereby animals adapt to humans and the captive environment they are provided (Price, 1999), is defined in numbers of various ways. Rindos (1980) postulate domestication to be a symbiotic evolutionary process between humans and animals or plants, where the domestication occurs before the origin and development of agricultural systems and is the reason why agricultural system develops. Contrary, Hale (1969) and Clutton-Brock (1977) simply suggested domestication to be a condition where breeding and feeding of animals are more or less controlled by humans. Already in the $19^{\text {th }}$ century Darwin $(1859 ; 1868)$ suggested domestication to be more than taming, that animals are bred in captivity, it is goaloriented, increases fecundity, could occur without conscious effort, increases plasticity and could reduce the size of certain body organs.

The domestication implies a transition from nature to captivity and brings about remarkable changes in the environment of the animal. For instance, the captive environment not always offers privacy for mating and rearing and protects against predators and aggressive social partners, as the natural environment (Price, 1999). The space available for captive animals is often reduced and food and water is provided at one single location and in sufficient quantities. As a consequence to this energy and time spent feeding is decreased and the movement and exploring behaviour of the animal is limited (Price, 1999). In addition, captive animals are more protected against predation and forced to live under higher population densities than in nature. The captive environment is often very different from the wild environment, which forces captive animals to adapt to their new situation (Price, 1999). The adaptation of animals to their captive environment tends to modify the morphology and other traits of animals towards what has been termed "the domesticated phenotype" (Jensen, 2006; Price, 1998). 


\section{The domesticated phenotype}

It has been an open question whether the suite of traits developed during domestication evolved as a result of selection on each of them independently, or whether they are to some extent a result of correlated side-effects to some major trait under selection. In the late 1950s the scientist Dmitry K. Belyaev started to select silver foxes (Vulpes vulpes) for one single behavioural trait -tameness. The effects were dramatic and the foxes started early in the selection process to act similar to dogs by being very friendly towards humans, wagging their tail, licking and seeking contact with the experimenter. The lowered fear response was further correlated to decreased plasma corticosteroid levels. Besides the changes in behaviour, the tame foxes also showed remarkable physiological changes. Already after eight to ten selected generations, the tame foxes displayed a change in coat colour, followed by floppy ears and curled tails. Thereafter, some individuals started to show shortened tail and legs (chondystrophy) and the skull proportions tended to be smaller and their nose shorter (brachycephaly). The sexual reproduction pattern also changed in the domesticated foxes. Sexual maturity started about a month earlier and the females gave birth to, in average, one more pup per litter. The mating season was lengthened and females bred out of season and sometimes mated twice a year (Trut, 1999).

The majority of the changes in traits and morphology that were described during Belyaev's selection experiment are actually shared among many different species of domesticated animals such as sheep, cow, horse, cat, dog and pig (Trut et al., 2009). The array of traits in which domesticated animals differ from their wild ancestors is known as the "domesticated phenotype". To summarize, the domestic phenotype differ from its wild ancestor by having a different colour of fur, skin or plumage, being brachycephalic and chondrodystrophic, having a reduced relative brain size, develop faster with increased reproductive capabilities, being less fearful and more sociable (Jensen, 2006; Price, 1998). It is fascinating that different species that became domesticated in different regions of the world and at different times are so similar and share so many phenotypic traits. This suggests that the domesticated phenotype is a general adaptation to captivity (Jensen, 2006), and further, that the array of traits 
included in the domesticated phenotype is a result of correlated side-effects to some major trait under selection rather than selection on each trait independently.

\section{The genetics of domestication}

Already in 1984 Price also added the genetic factor to the definition of domestication when he described it as "that process by which a population of animals becomes adapted to man and the captive environment by some combination of genetic changes occurring over generations and environmentally induced developmental events reoccurring during each generation" (Price, 1984).

When human started to breed animals for captivity, a radical change in selection pressure occurred. Price (1998) described three central processes in domestication. Firstly, relaxation of natural selection, secondly, natural selection under captivity leading to adaptation and thirdly, an intensified selection of traits preferred by humans, where the latter is unique for domestication (Price, 1999).

Belyaev suggested docility toward humans to be the main target of selection in the early beginning of domestication, and showed with his breeding experiment that selection for one trait could bring correlated responses in other traits (Trut et al., 2009). How can that be?

Genes control behaviour and other physiological traits, and one explanation for correlated selection responses is that one gene can act on more than one single trait. This phenomenon is known as pleiotropy. One well known example of pleiotropy comes from the frizzle gene in chickens. The frizzle gene not only causes feathers that are curled outward from the body of the bird, but also affects body temperature, metabolic and blood flow rate and increases digestive capacity (Lobo, 2008a). Another explanation for correlated selection of traits could be linked genes. When two genes are closely located to each other on the chromosome they are often inherited together. The phenomenon of genetic linkage was discovered through studies of heredity in fruit flies by Thomas Hunt Morgan, who noticed that the eye colour in the fly was associated with sex and therefore must be linked (Lobo, 2008b). It is important to take into consideration the underlying genetic architecture when studying complex traits 
such as behaviour, and it is often difficult to determine if correlated selection responses are due to one pleiotropic gene, genetic linkage or other genetic interactions not mentioned here.

In order to evaluate the genetic effects on phenotype, the genes must first be discovered. There are different tools for this and the two relevant for this thesis will be briefly mentioned here.

\section{QTL-analyses}

In quantitative trait locus (QTL) -analysis two strains that differ genetically and phenotypically on a trait of interest are crossed into a heterozygous $F_{1}$ progeny, and further into a $F_{2}$ population. All individuals from the $F_{2}$ population are scored for the trait of interest and several types of genetic markers that distinguish between the two original strains. Statistical analyses are used in order to evaluate the probability that a marker, or an interval between two markers, is associated with a QTL affecting the trait (Miles, 2008). When a QTL of interest is found, a more narrow analysis of that chromosomal area is done in order to pinpoint candidate genes that could have an effect on the trait in question.

\section{Selective sweeps}

Genomic scans for selective sweeps is another method. A selective sweep is an area in the genome with little or no variation. The sweep is the result of a beneficial novel mutation that becomes highly frequent in a population through natural or artificial selection. The surrounding genes will hitch-hike along with the mutated allele to a high frequency, creating a selective sweep (Nielsen et al., 2005). It is therefore very likely that a selective sweep within one population contains a mutation that is correlated to a valuable phenotypic trait that has been a target for selection.

\section{The chicken as a model species}

In this thesis chickens are used as an animal model to study domestication. The domestic breeds of chicken that we have today all originates from the ancestral Red Junglefowl (Gallus gallus) (Fig 1). The Red Junglefowl is a shy bird that lives wild in small social groups in the Southeast Asia, and it also exists in zoos and lab populations. The plumage of both males and females is dark pigmented with brown 
and black feathers, and the long tail feathers of the male shimmers with blue and green. In the wild, the main breeding season is from April-June and the female incubates a clutch of 3-7 eggs (Collias and Collias, 1967). The domestication of the Red Junglefowl started about 8000 years ago (Siegel et al., 1992; West and Zhou, 1988). It is unclear what the leading purpose of the domestication initially was, but today two main categories of birds exists: birds bred for rapid growth and meat production (broilers) and birds selected for high egg production (layers) (Fig 1). The White Leghorn is one of the most common layer breeds, often kept in large groups at high densities in the industry. The bird has a pure white plumage without any markings or patterns. The female lays 200-300 eggs per year, where each egg weights more than double than those of the Red Junglefowl, and she rarely incubate her eggs (Schütz, 2002).

Besides the obvious phenotypic differences described for the White Leghorn and Red Junglfowl, they also differ with respect to behaviour. In general, the White Leghorn is less active, shows a less intense social behaviour and lower frequency of social interactions, has a reduced antipredator behaviour and lowered response towards a fearful stimulus (Campler et al., 2009; Schütz et al., 2001; Schütz and Jensen, 2001).

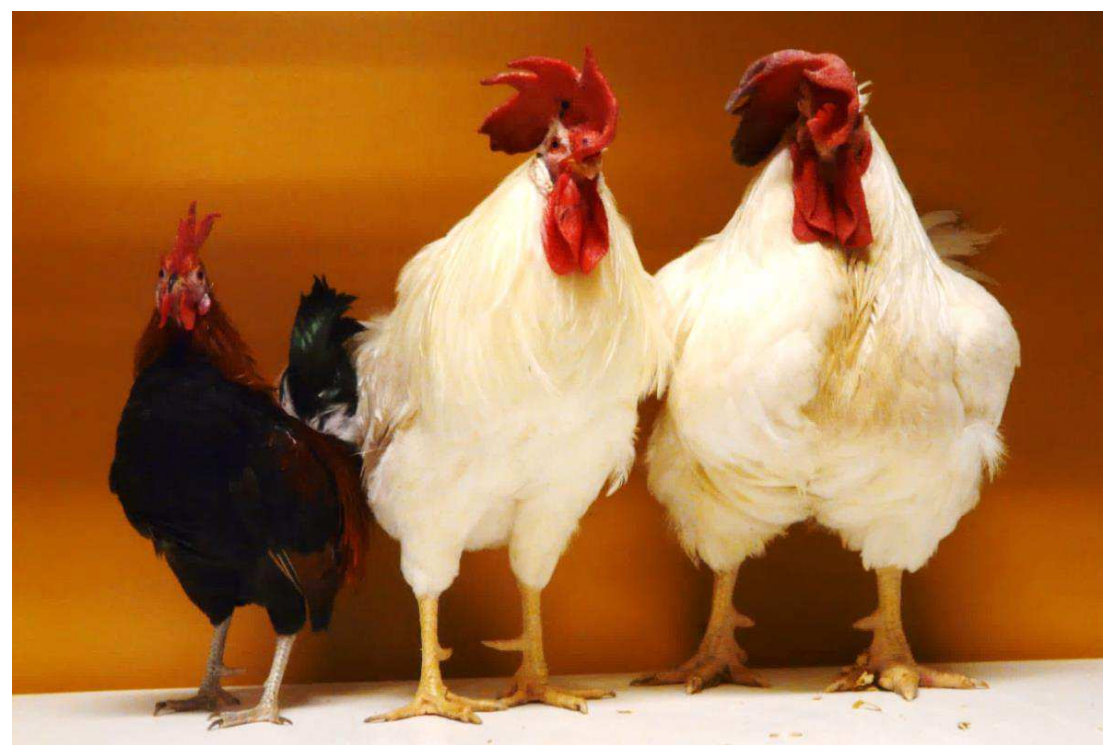

Figure 1. From left: Red Junglefowl male, White Leghorn male, Broiler male. Photo: A-C. Karlsson. 
It is apparent that the life and phenotypic characters of the modern chicken differs remarkably from that of the Red Junglefow. Since crossing between breeds and their ancestors is possible, together with a relatively short generation time, the chicken offers an excellent model to study domestication. Furthermore, artificial incubation and controlled rearing with no influence from the mothering hen enables a standardized environment to study genetic variations in physiological and behavioural traits.

\section{The Locus controlled Advanced Intercross Line}

In order to investigate the effect of single genes on phenotypic traits a so called Locus controlled Advanced Intercross Line (LAIL) has been used in the studies presented in this thesis. The LAIL is an advanced intercross line in which the genotype of a locus under interest is kept constant and controlled. An advanced intercross line is created by breeding two strains that differs genetically and phenotypically, in this case Red Junglfowl with White Leghorn, into a F1 generation. The $\mathrm{F}_{1}$ generation is further used to generate $F_{2}$ individuals and so on. Repeated intercrossing, i.e. using the previous generation to generate the next, forms an advanced intercross line. For each generation new recombination events are introduced, causing a mosaic genome, with randomly occurring combinations of alleles from the founder individuals, and thereby decreasing linkage disequilibrium (the non-random association of alleles at two or more loci) (Besnier et al., 2011; Darvasi and Soller, 1995). To control for one particular locus, each individual is genotyped for the gene or genetic marker of interest, and the homozygous animals are used for further comparisons of phenotypic traits. With this method it is possible to study the effects of the genotype on one locus against a random background mixture between the original parental chromosomes. If consistent differences in a trait are found between two homozygotes in a LAIL, this trait is likely influenced by the controlled locus.

\section{The PMEL17 gene}

In a QTL analysis of an F2 generation of White Leghorn x Red Junglefowl, a QTL affecting plumage colour was associated to the Dominant white locus, for which the 
White Leghorn and the Red Junglefowl were fixed for different alleles (Kerje et al., 2003). The Dominant white allele is associated with the white, non-pigmented plumage characteristic for the White Leghorn. It has been exclusively correlated to a 9-base pair insertion in exon 10 of the PMEL17 gene, leading to an insertion of three amino acids, which causes a dysfunctional transmembrane region in the protein that unable melanin deposition (Kerje et al., 2004). Therefore, chickens that are homozygous for the Dominant white allele have no mature eumelanosomes, and show a completely non-pigmented plumage, contrary to the dark pigmented Red Junglefowl (Fig. 1). The PMEL17 gene is not directly involved in the melanin synthesis (Theos et al., 2005), but is located in the vesicular structures of premelanosomes and plays an important role in the maturation of premelanosomes into melanosomes (Raposo et al., 2001). The PMEL17 protein is essential in the amyloid fibril formation that occurs during premelanosome maturation (Huff et al., 2003), and serve as the site of melanin deposition in pigment cells of skin, hair, feathers and eye (Yasumoto et al., 2004).

\section{Coat colour and domestication}

The change in coat colour is among the first responses due to domestication, and probably also the most striking one. During domestication the proportion of white or spotted animals in the population increases rapidly (Price, 1998). Studies have shown that colour phenotype may be linked to behaviour selected during domestication. The most famous example comes from the already mentioned farm-fox experiment. The first notable change that occurred when foxes were bred for tameness, was loss of pigmentation in certain areas of the body creating the so called piebald coat colour. This colour pattern is today shared among numerous domestic breeds such as dog, pig, horse and cow (Trut, 1999). The loss of pigmentation, hypopigmentation, occurring as a side effect during domestication could indicate that low pigmented phenotypes adapt easier to cope with the stress of captivity. There are studies of mink and sables that further support this theory, where randomly bred non-pigmented individuals have been described as "naturally tame" in comparison to dark pigmented individuals when handled by humans, even without any selection for tameness (Keeler and Moore, 1961; Trapezov et al., 2008). In a literature review of pleitropic effects on behaviour and colouration in wild populations of vertebrates, Ducrest et al., (2008) conclude that 
darker wild vertebrates are more aggressive and sexually active than lighter individuals, but in contradiction to our hypothesis, also more resistant to stress than lighter individuals

\section{Feather pecking and PMEL17}

Feather pecking is an abnormal behaviour among different species of fowl kept in captivity, where feathers are pecked at or removed from one bird by another (Fig. 2). The behaviour can lead to cannibalism and is therefore a severe welfare problem often seen in the poultry industry (Dixona, 2008). Studies of individuals selected for being homozygous for either the PMEL17 wild type allele or the Dominant white allele showed that pigmented wild type individuals were more exposed to feather pecking than non-pigmented dominant white chickens (Keeling et al., 2004a). This was confirmed by (Nätt et al., 2007) who, not only showed that homozygous wild type females were more exposed to feather pecking than homozygous Dominant white females, but also that the genotypes seemed to differ in social behaviour.
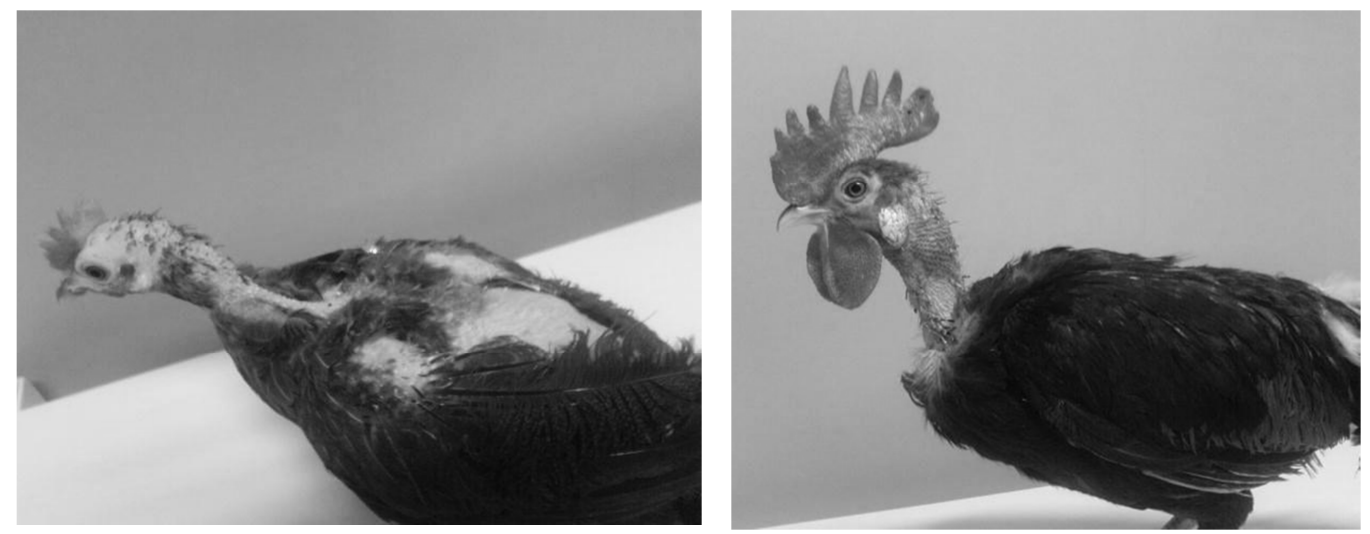

Figure 2. Feather pecked Red Junglefowl female (left) and male (right). Feathers missing on back and neck. Photo: A-C. Karlsson.

\section{Pigmentation and the eye}

In the eye, the retinal pigmented epithelium (RPE) is a pigmented cell layer in the retina that lies in close association with the rod and cone photoreceptors. The epithelium has diverse features, and a dysfunctional RPE leads to photoreceptor death and impaired vision (Bok, 1993). PMEL17 is expressed in RPE cells and mutations in 
the gene are in several species associated with various ocular defects (Dausch et al., 1978; Ewart et al., 2000; Gelatt et al., 1981; Grahn et al., 2008; Ramsey et al., 1999), such as hypopigmentation of the RPE causing photoreceptors that are strongly reduced in length or absent (Schonthaler et al., 2005). In previous studies the White Leghorn has shown poorer performance in learning tasks requiring a good visual ability in comparison to the Red Jungle fowl (Lindqvist et al., 2007; Lindqvist et al., 2002). It is possible that the White Leghorn suffers from ocular abnormalities due to the Dominant white mutation in the PMEL17 gene. This could explain why the White Leghorn differs from the Red Junglefowl, not only in particular behavioural tests (Lindqvist et al., 2007; Lindqvist et al., 2002), but also in general behaviours such as fear and sociality (Campler et al., 2009; Schütz et al., 2001; Schütz and Jensen, 2001).

\section{The TSHR gene}

A few years ago a whole-genome resequencing study was done in order to identify selective sweeps and possible candidate mutations that could have been important for the domestication of the chicken. Eight populations of domestic chickens representing both egg laying and meat producing lines, together with populations of Red Junglefowl were used. One of the most striking selective sweeps, with almost complete fixation in the domestic breeds, but not in Red Junglefowl, occurred at the locus encoding the thyroid stimulating hormone receptor (TSHR) on chromosome 5. In a further analysis of the TSHR region 264 out of 271 domestic chickens representing 36 populations of different geographic origins were homozygous for the sweep, and the remaining 7 birds heterozygous. In other words, all individuals from a domesticated population carried at least one mutant allele, indicating that TSHR may be a domestication locus in chicken. A missense mutation resulting in an amino acid substitution was identified as the candidate mutation for the TSHR sweep (Rubin et al., 2010).

\section{The hypothalamus-pituitary-thyroid axis}

The TSHR plays an important key role in the signal transduction of the hypothalamuspituitary-thyroid axis and it is mainly located at the surface of the thyroid follicle cells. 
The binding of the TSH ligand to its receptor stimulates the synthesis and release of thyroid hormones from the thyroid gland into the blood stream. The thyroid hormones triiodothyronine (T3) and thyroxin (T4) are known to have either direct or indirect effects on metabolism, gene regulation, development and growth, reproduction, pigmentation and behaviour (reviewed by Crockford, 2006). The traits known to be affected by thyroid hormones are very similar to the ones described to constitute the domesticated phenotype, indicating the possible relation between the TSHR sweep and chicken domestication. Another interesting connection between TSHR and domestication is one of the most powerful characteristics in domesticated animals, namely, the loss of strict seasonal reproduction.

\section{TSHR and the control of seasonal reproduction}

In temperate regions animals reproduce on a seasonal basis. Offspring is generated during spring and summer when food is available to increase the chances of survival and hence, increase reproductive fitness. In order to do adapt to seasonal changes in the environment, the animals have to rely on annual information where day length has been shown to be the dominant cue for seasonal responses (Yoshimura, 2013). The loss of strict seasonal reproduction is one of the most remarkable traits within the definition of the domesticated phenotype, and it is apparent in many domestic variants of species such as sheep, cattle, pig, cat and dog (Faya et al.; Setchell; Trut, 1999). Although populations of the Red Junglefowl kept in zoos and labs may have undergone some unintended adaptation just by being kept in a captive environment, and therefore differ from wild populations in terms of reproductive traits, there are still obvious differences in the reproduction pattern when comparing Red Junglefowls to White Leghorns. Captive Red Junglefowls kept under standard lab conditions under a 12/12 light/dark cycle lay eggs with a weight half of that of a White Leghorn, and produces ten times fewer eggs per year (Schütz, 2002). A less strict seasonal reproduction could have been a main target for positive selection during domestication because it allows captive animals to reproduce regardless of season and to mate more than once per year. 
The TSHR is not only expressed in the thyroid follicle cells, but also in the mediobasal hypothalamus, where it is involved in the signal transduction of photoperiodic response. The mechanisms of photoperiodic signaling can be described in the following steps (Nakao et al., 2008; Yasuo et al., 2005; Yoshimura, 2013) (illustrated in Fig. 3):

- Ligh information is received by the deep brain photoreceptor Opsin 5. Light penetrate into the hypothalamus. Opsin 5 is a violet sensitive photopigment located in cerebrospinal-fluid-contacting neurons in the paraventricular organ of the mediobasal hypothalamus. Activation of Opsin-5 induces expression of TSH in the pars tuberalis (thin cell layers surrounding the pituitary stalk, which connects the median eminence with the anterior pituitary gland).

- TSH binds to TSHR and upregulates DIO2. The TSHR is localized in ependymal cells lining the third ventricle and when the TSH-ligand bind to it, expression of the thyroid hormone activating enzyme type 2 iodothyronine deiodinase (DIO2) is induced.

- DIO2 converts T4 to T3. There is a 10-fold increase in T3 content within the mediobasal hypothalamus during long-day conditions compared to short-day conditions.

- T3 causes morphological changes in the Gonadotropin-releasing hormone (GnRH) nerve terminals and glial processes. GnRH nerve terminals are in close proximity to the basal lamina under long-day conditions, which enables GnRH secretion into the hypophyseal portal blood. During short-day conditions the GnRH terminals are encased by the end-feet and no GnRH is secreted. 
- GnRH secreation causes a release of follicle-stimulating hormone and luteinizing hormone from the anterior pituitary gland. Resulting in an increase in ovary size and induced testicular growth.

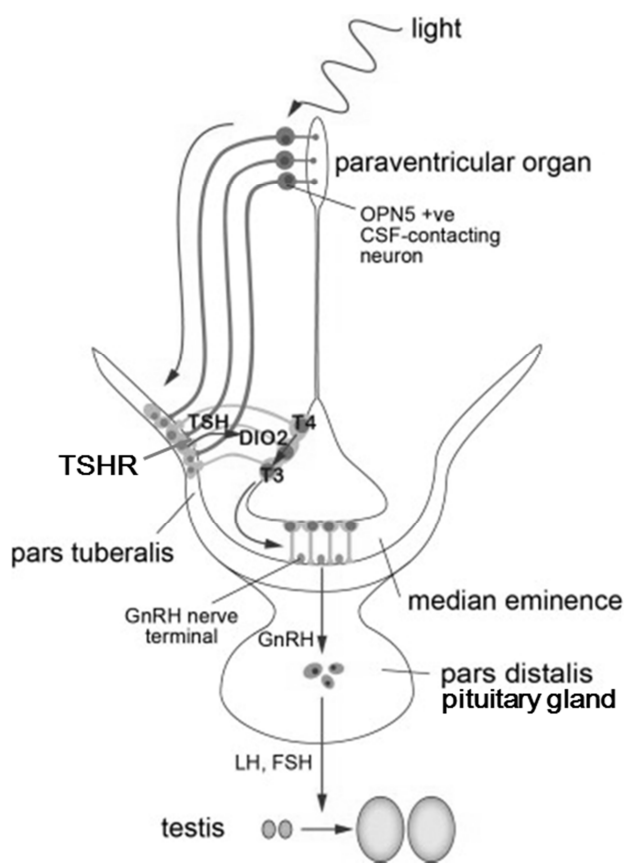

Figure 3. Photoperiodic signal transduction cascade in bird. Picture modified from (Yoshimura, 2013).

Since TSHR influences behaviour and physiological traits (via thyroid hormones) as well as photoperiodic regulation (as an important link in the signal transduction in the mediobasal hypothalamus), together with the fact that the domestic TSHR allele is fixed in domestic breeds of chicken, the gene is suggested to be a possible "domestication gene" in chicken. 
The general aim of this thesis was to study the effect of a mutation in two domestication related genes (PMEL17 and TSHR) on behaviour, physiology and gene expression in chicken.

\section{Paper I}

The aim was to study social and explorative behaviour in chickens homozygous for the Dominant white or wild-type allele of PMEL17 and further investigate if the gene was expressed in brain.

\section{Paper II}

A follow-up study to Paper I where the aim was to investigate the effects of the PMEL17 genotype on behaviour when effects of early negative social experiences were excluded.

\section{Paper III}

The aim was to examine whether the Dominant white mutation affects the visual ability and gives rise to ocular abnormalities in chickens.

\section{Paper IV}

The aim was to study possible differences in development (incubation time), behaviour and thyroid hormone levels between chickens homozygous for the domestic or wildtype allele of the TSHR gene.

\section{Paper $V$}

The aim was to investigate the effect of the TSHR mutation on gonadal size and gene expressions in brain as a response to a change in day length (photoperiod). 


\section{Summary of papers}

\section{Paper I}

Method: We studied behaviour and brain gene expression in chickens homozygous for the Dominant white or wild-type allele of PMEL17, generated from a Red Junglefowl $\mathrm{x}$ White Leghorn LAIL. The behavioural studies consisted of three social and one explorative behaviour test.

Results and conclusions: There were significant differences between genotypes in both social and explorative behaviour, where homozygous wild type PMEL17 birds were more sociable and explorative than Dominant white birds, with a more pronounced effect in females. No expression of the PMEL17 gene was found in brain. In conclusion, the PMEL17 gene has pleiotropic effects on social and explorative behaviour but is not expressed in brain.

\section{Paper II}

Method: Chickens homozygous for the Dominant white or wild-type allele of PMEL17, generated from a Red Junglefowl x White Leghorn LAIL, were tested for social, aggressive, fear and exploratory behaviours. Furthermore, corticosterone and testosterone levels were assessed. To exclude effects of early negative social experiences, such as feather pecking, the chickens were individually housed without physical contact but allowed visual and auditorial contact, from the day of hatching.

Results and conclusions: The wild type PMEL17 birds scored higher on the factor explaining active/exploratory and social behaviour in a principal component analysis then the homozygous Dominant white individuals. Wild type males were also significantly more aggressive in comparison to Dominant white males. There were no significant differences in corticosterone or testosterone levels between genotypes. In conclusion, the pleiotropic effects of PMEL17 on behavoiur remained when negative social behaviours were excluded. 


\section{Paper III}

Method: Chickens homozygous for either the Dominant white mutation or the wild-type allele, generated from a Red Junglefowl x White Leghorn LAIL, were tested in a visual contrast behavioural test. Furthermore, ophthalmologic and histologic examinations of the eyes were done.

Results and conclusions: There were no differences between genotypes in the visual contrast behavioural test, and no abnormal structures among the Dominant white chickens were seen in the ophthalmic examination. The histological sections did not reveal any differences between genotypes in structure, photoreceptor density, or RPE pigmentation. In conclusion, a mutation in the PMEL17 gene does not affect visual ability in chicken.

\section{Paper IV}

Method: Development (incubation time), behaviour and thyroid hormone levels were measured in chickens from a Red Junglefowl x White Leghorn LAIL homozygous for the wild type allele, heterozygous or homozygous for the mutant "domestic" allele at the TSHR locus. The behavioural studies measured general activity, sociality and fear responses to a human.

Results and conclusions: Birds homozygous for the "domestic" allele at the TSHR locus had a longer incubation time, males but not females showed less fearful behaviours in a fear of human-test, females but not males showed a lower number of aggressive behaviours in a social dominance-test, and both sexes showed a decreased levels of plasma T4. In conclusion, the mutation in the TSHR gene affects several traits related to domestication in a direction that mirrors the behaviour and physiology of pure domesticated White Leghorns.

\section{Paper $V$}

Method: Chickens from a Red Junglefowl x White Leghorn LAIL homozygous for the wild type allele or homozygous for the mutant "domestic" allele at the TSHR locus were subjected to a shortening in day length in order to measure gonadal photoperiodic response. In addition to this, the expressions of the TSHB, THSR, DIO2 and DIO3 
genes were measured in hypothalamus. Pure White Leghorn and Red Junglefowl females kept under natural day length were included in the study as controls.

Results and conclusions: TSHR gene expression differed significantly for both females and males in all populations, indicating a strong effect of the "domestic" mutation on gene expression. Female "domestic" homozygotes showed a faster increase in the onset of laying, in comparison to homozygous wild types. Males homozygous for the wild type allele showed a stronger response to altered day length in testicular size and significant difference in DIO3 expression, in comparison to homozygous "domestic" males. Pure White Leghorn females kept under natural day length in Sweden during December showed active ovaries and significant lower levels of $\mathrm{DIO} 3$ in comparison to Red Junglefowl females kept under similar conditions. In conclusion, the TSHR mutation affects photoperiodic response in chicken in the direction of being less dependent on seasonal reproduction, a typical domestication feature. 
This thesis has focused on two genes: PMEL17 and TSHR. Both are genes related to domestication, where a mutation in each gene is fixated in one or several domestic breeds of chicken. In this thesis we have shown that both genes have pleiotropic effects on behaviour and physiological traits related to domestication.

\section{PMEL17}

Feather pecking is a detrimental behaviour where one bird peck at the feathers of other birds, sometimes pulling the feathers out and eating them. It may result in wounds on the skin of the victimized bird, and sometimes even lead to cannibalism (Blokhuis and Wiepkema, 1998). A mutation in the PMEL17 gene is associated with a nonpigmentation of the plumage, and a reduced risk of feather pecking victimization (Keeling et al., 2004b; Nätt et al., 2007). Nätt et al. (2007) showed that PMEL17 genotype affect several behaviour patterns which are not immediately linked to feather pecking. For instance, homozygous wild type individuals showed a higher degree of vocal based social reinstatement behaviour under open-field conditions than birds homozygous for Dominant white. The study in paper I further confirmed the findings by Nätt et al. (2007) by showing that homozygous wild type PMEL17 birds were more sociable and explorative than Dominant white birds.

Feather pecking is suggested to be a form of redirected ground-pecking behaviour (Blokhuis, 1986) or a redirection of substrate pecking during dust bathing (Vestergaard et al., 1993). It is also reported that feather pecking is positively correlated with increased group size (Riedstra and Groothuis, 2002) and that feather pecking increase significantly in groups that are rehoused with unfamiliar peers, suggesting that feather pecking has an underlaying social component (Riedstra and Groothuis, 2002). Moreover, studies have shown that plumage colour could play a role for feather pecking victimization. For instance, Oakham Blue birds with white plumage had less feather damage due to feather pecking than black or grey birds. The suggested 
explanation was that dark birds were less visible to conspecifics than white birds in the dim, artificial lights inside the poultry house, and this novel appearance could make them more susceptible to feather pecking (Bright, 2007). Savory and Mann (1999) also found that more pecks at litter particles on the plumage were directed towards dark birds than white, and suggested light-coloured particles on dark plumage to be a more potent pecking stimulus than dark particles on light plumage.

The causes of feather pecking remain unclear. However, the studies of PMEL17 show that genotype at this locus, and hence plumage colour, correlates with the risk of being a victim of feather pecking and further, that it affects behaviour (Karlsson et al., 2010; Keeling et al., 2004b; Nätt et al., 2007). It could be that the behavioural differences between genotypes makes wild type birds more exposed for victimization, or perhaps the dark plumage colour expressed in wild type birds itself attracts feather pecking as suggested in previous studies (Bright, 2007; Savory and Mann, 1999). If the latter is true, it could be that the experience of being a victim of feather pecking in turn affects various aspects of the behaviour.

In paper II we wanted to exclude indirect effects on behaviour of being a victim of feather pecking at a young age, by studying birds raised in physical isolation. The results coincided with the results from paper I and showed that wild type PMEL17 birds were more active, explorative and sociable. Moreover, wild type males were significantly more aggressive in comparison to Dominant white males. Hence, a mutation in the PMEL17 gene seems to affect sociality (defined as the motivation to be with other conspecifics) and explorative behaviour in a negative direction. Social behaviour, and in particular sociality, has been associated to feather pecking in earlier studies. Riedstra et al. (2002) observed no clear relationship between feather pecking and ground pecking, but instead associated feather pecking with other socially orientated pecks and argued that gentle feather pecking at an early age plays an important role in the building and maintenance of social relationships between chicks. Furthermore, birds from a high feather pecking line showed an increase in vocalisations (considered to be a social behaviour) with increased age, whereas birds selected for low feather pecking showed a decrease over time (Rodenburg and Koene, 
2003). Even in Japanese quail (Coturnix coturnix japonica) increased feather pecking was observed in a line selected for a high social motivation compared to a line selected for low social motivation (Bilcik and Bessei, 1993). However, Jones et al. (1995) found opposite correlations between sociality and feather pecking in domestic chicks, where females from a genetic line showing low feather pecking levels had higher social motivation than birds from a line of high feather pecking. The correlation between social behaviour and feather pecking may be vague, but from the results in paper I and II combined with previous studies (Karlsson et al., 2011; Karlsson et al., 2010; Keeling et al., 2004b; Nätt et al., 2007) we can conclude that a mutation in the PMEL17 gene decreases the risk of becoming a victim of feather pecking and alters behaviour. How these two traits are related remains to be investigated.

In a previous study, White Leghorn chickens from a high feather pecking line showed a stronger stress response to a manual restraint test, resulting in higher levels of plasma corticosterone after restraint than birds from a low pecking line (Kjaer and Guémené, 2009; Korte et al., 1997). In paper II a similar restraint test was performed in the PMEL17 chickens. Physical restraint caused a significant increase in corticosterone levels, but there were no differences between the genotypes in either basal or stress levels, indicating that the Dominant white mutation does not seem to affect neurosympathetic and adrenal responsivness. So, how could a mutation in the PMEL17 gene be related to the behavioural differences observed in paper I and II? Nätt et al. (2007) suggested one possible theory on how the PMEL17 gene could exert its effect on behaviour; melanin is synthesised from tyrosine and uses L-DOPA as a close precursor. L-DOPA is also used in the production of catecholamines (dopamine, epinephrine and norepinephrine) which are all well known to affect behaviour and physiological responses (Fig. 4). An accumulation of eumelanin due to the PMEL17 mutation could alter the biochemical equilibrium and thereby the concentrations of different catecholamines, that in turn would affect behaviour (Nätt et al., 2007). What further supports this theory is the close connection between dopamine and melanin in the pigmented dopaminergic neurons in the substantia nigra in humans, where neuromelanin is oxidated from cytosolic catecholamines (Sulzer et al., 2000). Furthermore, RPE cells are used as pharmacological therapy in the treatment of 
patients with Parkinsson's disease, because RPE cells secretes L-dopa and small quantities of dopamine during the melanogenesis, and transplantation of human RPE cells into striatum of patients with Parkinsons' disease has been shown to have beneficial effects (Ming et al., 2009). What is contradictory to this theory is the fact that he PMEL17 gene is not expressed in the chicken brain, as shown in paper I. However, it is still plausible that the gene is expressed during embryonic development, as seen in mouse embryos (Baxter and Pavan, 2003). If so, in theory, the Dominant white mutation could perhaps alter the release of catecholamines which in turn affects neural formations critical for further development of behaviour.

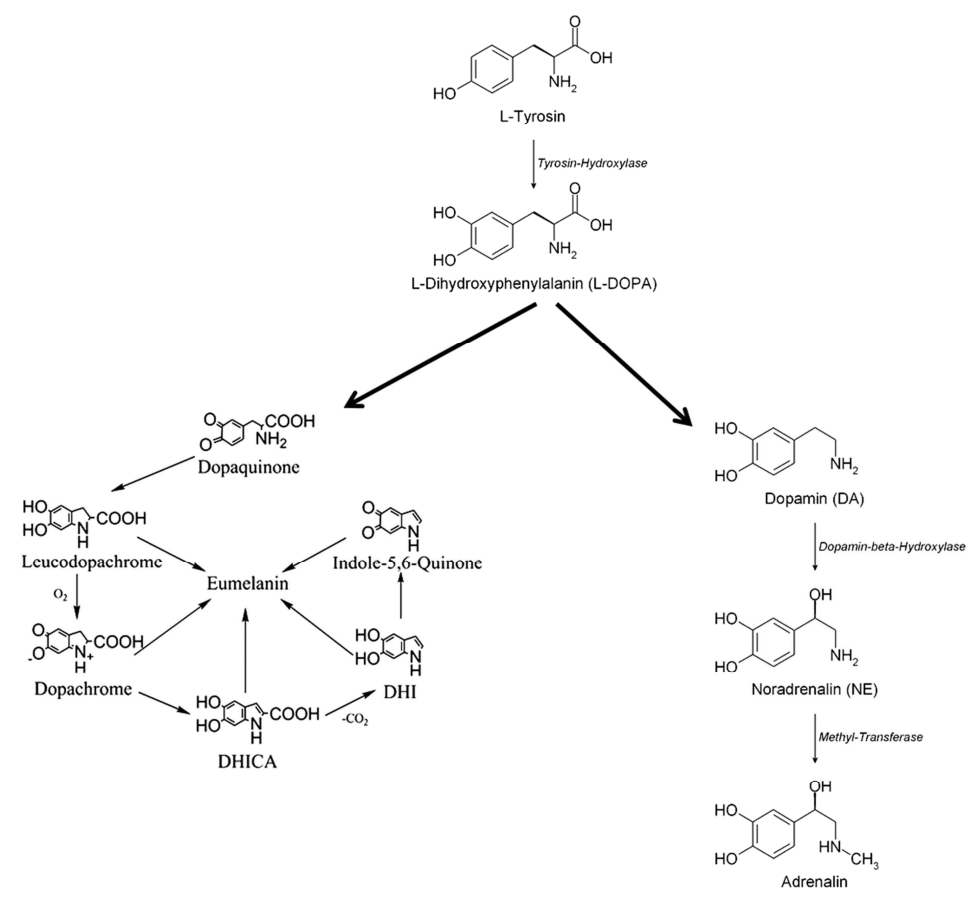

Figure 4. The melanin synthesis (to the left) is closely related to the catecholeamine synthesis (to the right) through L-DOPA from which both eumelanins and catecholeamins (dopamnine, norepinephrine and epinephrine) are synthesized. 
Another theory could be that melanocytes in the epidermis, that produces melanin for feathers, releases dopamine similar to that of RPE cells. Studies have shown that stress-related physical immobilization increases circulating concentrations of melanocyte-stimulating-hormone ( $\alpha$-MSH) in male rats (Lindley et al., 1990), which in theory should stimulate melanin synthesis and perhaps thereby also increase dopamine levels. The relation between dopamine and melanin production in pigment cells is further supported by a study in mice showing that stimulation of dopamine receptors inhibits melanin synthesis in hair follicular melanocytes (Burchill and Thody, 1986).

A completely different theory could be that the mutation in PMEL17 is causing visual impairment by affecting the pigmentation of the retinal pigmented epithelium, and further alters the behaviour of homozygous Dominant white birds towards being less active, explorative, social and aggressive. In horses a mutation in the PMEL17 gene is associated with the silver coat colour which is characterized by dilution of the black pigment in the hair (Brunberg et al., 2006). Icelandic horses with silver coat colour are more cautious in novel situations and one likely explanation for this difference is that the Silver mutation in PMEL17 is associated with multiple congenital ocular anomalies (Brunberg et al., 2006). Therefore, the effect of a mutation in the PMEL17 gene on visual ability in chicken was investigated in paper III. The results showed no signs of visual impairment or abnormalities in the eye of homozygous Dominant white chickens, supporting the theory that the PMEL17 gene has a more direct effect on behaviour.

\section{TSHR}

In this thesis we have examined the effect of a mutation in the TSHR gene (described by Rubin et al., 2010) following two main lines. In paper IV we investigated general effects on development, behaviour and plasma thyroid hormone levels, and in paper $\mathrm{V}$ we focused on the photoperiodic regulation system in brain.

The results in paper IV showed that the mutation affects incubation time, fearful and aggressive behaviours as well as levels of plasma T4. Moreover, the results in paper V 
showed that TSHR genotypes differ in phenotype and gene expressions in response to altered day length. Our studies clearly show that the mutation in the TSHR gene affects phenotype in chicken. The phenotypic effects of the mutation mirrors the differences in development, behaviour and photo responses between pure domesticated White Leghorns and pure Red Junglefowl chickens, where White Leghorns hatch later, show less fear towards humans, decreased aggressive behaviour towards conspecifics and produces more eggs independent of season, in comparison to the Red Junglefowl.

So, how can the THSR mutation cause these phenotypic alterations found in our studies? The candidate mutation for the selective sweep over TSHR is a nonconservative amino-acid substitution, where glycine is substituted for arginine at residue 558. A bioinformatic analysis suggests that the shift from glycine to argenine pushes the residue, located at the border between transmembrane region 4 and following extreacellular loop of the $G$ protein-coupled receptor, outwards from the membrane and may therefore influence ligand interaction (Rubin et al., 2010). One could speculate that an altered ligand interaction would affect the production and secretion of the thyroid hormones thyroxin (T4) and triiodothyronine (T3) from thyroid follicular cells into the blood, which was also suggested in the results from paper IV. Both females and males of the TSHR $d / d$ genotype had significantly lower levels of free plasma T4 in comparison to the $w / w$ genotype, indicating that the mutation decreases the secretion of thyroid hormones into blood. The phenotypic differences between TSHR genotypes further supports this theory. Studies have showed that embryos treated with different TH inhibitors have a delayed, or even inhibited, hatching (reviewed by De Groef et al., 2013; Decuypere and Kühn, 1988). Similarly, our TSHR $d / d$ chickens have a longer incubation time than the $w / w$ genotype, as shown in paper IV.

$\mathrm{T} 4$ is a prohormone to T3 and in plasma, levels of T4 is 40 times higher than T3. T4 can be converted to $\mathrm{T} 3$ by deiodination of its outer ring, or inactivated to reverse $\mathrm{T} 3$ (rT3) by inner-ring deiodination. Two types of deiodinases catalyses the reactions. Deiodinase 2 (D2 or DIO2) converts T4 to bioactive T3, and deiondinase 3 (D3 or DIO3) inactivates $\mathrm{T} 4$ to $\mathrm{rT} 3$ and $\mathrm{T} 3$ to $\mathrm{T} 2$. Thyroid hormones are transported into 
cells, or over the blood brain barrier into brain by specific thyroid hormone transporters. Thyroid hormones exert their effects mostly at the genomic level, by interacting with specific nuclear receptors, but also through non-genomic mechanisms (Kuehn and Lozada, 2009).

The TSHR gene is mainly expressed in the thyroid follicle cells, even though expression of the gene has been found also in non-thyroid tissues, such as hepatocyte (Zhang et al., 2009), adipocytes (Endo and Kobayashi) and skeletal muscle cells (Jung Hun et al., 2013). In Japanese quail transferred from short days to long days, a strong expression of TSHR was observed in the ependymal cells and pars tubelaris in hypothalamus at 6 and 22 hours after dawn of the first long day. Further investigations demonstrated that thyroid-stimulating hormone (TSH) regulates the expression of DIO2 through TSHR, resulting in a release of luteinizing hormone (Nakao et al., 2008). Hence, TSHR is believed to play an important role in the signal transduction pathway triggered by long-day photoinduced seasonal breeding. With this as background we aimed to investigate the effects of the mutation on photoperiodic responses in our TSHR genotypes in paper V. The overall higher expression in wild type homozygous females and males in all populations tested show that the mutation affects the TSHR gene expression by decreasing mRNA levels. The data further shows that "domestic" males are not as responsive towards an altered day length as wild type males. Interestingly, another remarkable trait from a domestication perspective appears to be affected by the TSHR mutation, namely the onset of laying, where the "domestic" females show a faster increase of egg laying in comparison to wild type individuals. In summary, the results from paper IV and V suggest that the TSHR mutation in chicken affects several phenotypic traits that are characteristic for domesticated chickens such as development, behaviour and reproductive traits.

The almost complete fixation of the TSHR mutation in domesticated breeds of chicken worldwide proposes that the mutation is old (Rubin et al., 2010). However, genetic investigations of ancient chickens from different European archaeological sites showed that the TSHR sweep was only fixed in Classical Greek chickens. The results suggest either that the mutation was not subjected to strong human-mediated selection 
until the past 500 years, or that the sweep became fixed in populations that originated outside Europe and that these birds replaced the initial populations introduced into Europe (Girdland Flink et al., 2014). The genotyping of 9 different Swedish landraces in paper $\mathrm{V}$ support the theory that the TSHR mutation is not related to the modern chicken industry. The chicken was introduced into to Sweden about 2000 years ago and the adaptation to local regions modified the chickens into different isolated populations that became the landraces we know today. The genotyping of the TSHR locus showed that eight out of nine Swedish landrace breeds were homozygous for the mutation and one heterozygous, indicating that the mutation was already fixed in the founder populations that arrived to Sweden. During the past 100 years poultry breeding has gone from traditionally farming to become a multinational industry, where animals are carefully selected to improve egg production traits in layer hens and meat production traits in broilers. If the TSHR mutation had been associated with modern commercial breeds it would be likely to assume that the main phenotypic effects of the genotype are egg production traits. However, the ancient origin of the mutation suggests that it is not primarily related to the modern traits of domestic chicken. The results from paper IV and V show that the mutation has pleiotropic effects on development, behaviour and photoperiodic response, which all correlates with the domestic phenotype. Therefore, the TSHR gene has probably been of selective advantage during the domestication of the chicken.

\section{In general}

Even if PMEL17 and TSHR are genes that differ much with respect to biological function and signal pathways, they share one common thing; both genes are strongly associated to the domestication of the chicken. The studies of PMEL17 and TSHR contribute to the understanding of animal domestication by demonstrating how genetic mechanisms can bring about correlated selection responses. Both PMEL17 and TSHR have pleiotropic effects on behavioural and physiological traits that are characteristic for domesticated animals, showing that the domesticated phenotype is most likely a result of pleiotropy from positively selected genes, rather than selection on each trait 
independently. The knowledge about genetic mechanisms, such as pleiotropy, and how single genes can affect several traits is useful from an animal welfare perspective. Breeding for single traits without considering underlying genetic mechanisms and the possibility of correlated selection responses could be devastating for the animal. However, conscious breeding and selection for single traits that positively affects the animal in several ways could, on the other hand, be used as a tool to increase animal welfare. 


\section{Conclusions}

Both PMEL17 and TSHR are genes where domesticated breeds of chicken are homozygous for a mutation in the respective genes, and the ancestral Red Junglfowl is homozygous for the wild type allele. Both genes affects domestication related traits that have been intentionally, or unintentionally, selected during domestication. Therefore, PMEL17 and TSHR are genes that have been important during the domestication of the chicken 


\section{Acknowledgements}

Without help from many people in my surrounding, this thesis would never exist. Thanks to everyone that have helped and supported me during my time as a $\mathrm{PhD}$ student!

In addition to this I would like to express my sincere gratitude to:

First of all, my supervisor professor Per Jensen. I am so grateful that you gave me the opportunity to become a $\mathrm{PhD}$ student. Thanks for your support, inspiration and never ending enthusiasm throughout all these years!

Professor Leif Anderson for your support and good advices during these years, and for all your valuable comments on my manuscripts.

Amir Fallahshahroudi for all help during the late night work at Vreta. For always being ready to go, no matter time, and for your super-efficient work in the lab. Now we know for sure -chicken ghosts do not exist.

My roomies Bea and Mia, and also Lina and Karin for all your support and encouragement! I will truly miss all our deep (and often not so deep) conversations that we have had during these years! You have really made my time as a PhD student to something very special!

Lejla Bektic and Petros Batakis for all your help with the chickens and in the lab. For all the hundreds of eggs you have picked and chickens you have weighed. Without you there would be no thesis.

Johanna Axling, Frida Svemer and Hanna Johnsen for your contributions to my studies. You have really added some important pieces to the story of this thesis.

Ann-Charlotte Svensson for all the help with the hormone analyses.

Jonas Eriksson at Uppsala University for helping me with the genotyping of my chickens. 
Daniel Nätt, Anders Wirén, Annelie Andersson, Jennie Westrander, Marcus Jöngren and Magnus Campler for helping me and inspiring me during my first years as a $\mathrm{PhD}$ student. In the lab, in the chicken house and in life.

Dominic Wright and Andrey Höglund for your input and help in my project, and to Hanne Løvlie and Rie Henriksen for taking your time to read through this thesis.

Susanne Kerje for your help and guidance with manuscript writing and in the (for me) novel world of ophthalmology.

Helena Wrisley and Jan Wretemark for taking care of the chickens at Vreta. I am sorry for all the times I made work difficult for you by covering entire rooms in plastics. You never complained and you should know that I really appreciated that!

All my fellow PhD students and colleagues at the Biology department for everything. You have all supported me in different ways even if you are not aware of it. I will especially miss all weird but really amusing conversations in the "fika"-room, which made me laugh almost every day!

All people in the AVIAN group for making it such a wonderful group to work in. Great people doing great work. A true source of inspiration!

Grandma Christina and Sara for always being by willing to take care of our children so I could spend my time with the chickens.

Hund-gänget because dogs, dogs, dogs is such a nice counterweight to chickens, chickens, chickens!

Lydia for being my best friend. So much has changed in our lives during these years, but our geeky dog interest remains! You are a very important person in my life, and I hope you know it!

Axel, for always being there. Without you, Tilde, Emil and the dogs life would be worth nothing. You are amazing, I love you! 


\section{References}

Baxter, L.L., and W.J. Pavan. 2003. Pmell7 expression is Mitf-dependent and reveals cranial melanoblast migration during murine development. Gene Expression Patterns 3:703-707.

Besnier, F., P. Wahlberg, L. Ronnegard, W. Ek, L. Andersson, P. Siegel, and O. Carlborg. 2011. Fine mapping and replication of QTL in outbred chicken advanced intercross lines. Genetics Selection Evolution 43:3.

Bilcik, B., and W. Bessei. 1993. Feather pecking in Japanese Quail—comparison of six different lines. In International Congress of Applied Ethology. M. Nichelmann, H.K. Wierenga, and S. Braun, editors. Berlin. 291-293.

Blokhuis, H.J. 1986. Feather-pecking in poultry: Its relation with ground-pecking. Applied Animal Behaviour Science 16:63-67.

Blokhuis, H.J., and P.R. Wiepkema. 1998. Studies of feather pecking in poultry. Veterinary Quarterly 20:6-9.

Bok, D. 1993. The retinal-pigment epithelium -a versitale partner in vision. Journal of cell science 189-195.

Bright, A. 2007. Plumage colour and feather pecking in laying hens, a chicken perspective? British Poultry Science 48:253 - 263.

Brunberg, E., L. Andersson, G. Cothran, K. Sandberg, S. Mikko, and G. Lindgren. 2006. A missense mutation in PMEL17 is associated with the Silver coat color in the horse. BMC Genetics 7:46.

Burchill, S.A., and A.J. Thody. 1986. Dopaminergic inhibition of tyrosinase activity in hair follicular melanocytes of the mouse. The Journal of endocrinology 111:233-237.

Campler, M., M. Jöngren, and P. Jensen. 2009. Fearfulness in red junglefowl and domesticated White Leghorn chickens. Behavioural Processes 81:39-43.

Clutton-Brock, J. 1977. Man-made dogs. Science 197:1340-1342.

Collias, N.E., and E.C. Collias. 1967. A Field Study of the Red Jungle Fowl in NorthCentral India. In Cooper Ornithological Society, 360.

Crockford, S.J. 2006. Rythms of Life: Thyroid Hormone \& the Origin of Species Trafford Publishing, Victoria, BC.

Darvasi, A., and M. Soller. 1995. Advanced Intercross Lines, an experimental population for fine genetic mapping. Genetics 141:1199 - 1207.

Darwin, C. 1859. The origin of species. Mentor, New York.

Darwin, C. 1868. The variation of animals and plants under domestication. John Murray, London.

Dausch, D., W. Wegner, W. Michaelis, and I. Reetz. 1978. Augenveränderungen beim merlesyndrom des hundes. Graefe's Archive for Clinical and Experimental Ophthalmology 206:135-150.

De Groef, B., S.V.H. Grommen, and V.M. Darras. 2013. Hatching the cleidoic egg: the role of thyroid hormones. Frontiers in Endocrinology 4:1-10.

Decuypere, E., and E.R. Kühn. 1988. Thyroid Hormone Physiology in Galliformes: Age and Strain Related Changes in Physiological Control. American Zoologist 28:401-415. 
Dixona, L.M. 2008. Feather pecking behaviour and associated welfare issues in laying hens. Avian Biology Research 1:73-87.

Ducrest, A.-L., L. Keller, and A. Roulin. 2008. Pleiotropy in the melanocortin system, coloration and behavioural syndromes. Trends in Ecology \& Evolution 23:502510.

Endo, T., and T. Kobayashi. 2012. Expression of functional TSH receptor in white adipose tissues of hyt/hyt mice induces lipolysis in vivo. American Journal of Physiology-Endocrinology and Metabolism 302:E1569-E1575.

Ewart, S.L., D.T. Ramsey, J. Xu, and D. Meyers. 2000. The horse homolog of congenital aniridia conforms to codominant inheritance. The American Genetic Association 91:93-98.

Faya, M., A. Carranza, M. Priotto, M. Abeya, J.D. Diaz, and C. Gobello. Domestic queens under natural temperate photoperiod do not manifest seasonal anestrus. Animal Reproduction Science 129:78-81.

Gelatt, K.N., G. Powell, and K. Huston. 1981. Inheritance of microphthalmia with coloboma in the australian shepherd dog. American Journal of Veterinary Research 42:1686-1690.

Girdland Flink, L., R. Allen, R. Barnett, H. Malmström, J. Peters, J. Eriksson, L. Andersson, K. Dobney, and G. Larson. 2014. Establishing the validity of domestication genes using DNA from ancient chickens. Proceedings of the National Academy of Sciences 111:6184-6189.

Grahn, B.H., C. Pinard, S. Archer, R. Bellone, G. Forsyth, and L.S. Sandmeyer. 2008. Congenital ocular anomalies in purebred and crossbred Rocky and Kentucky mountain horses in canada. Canadian Veterinary Journal 49:675-681.

Hale, E.B. 1969. Domestication and the evolution of behaviour. In The behaviour of domestic animals. E.S.E. Hafez, editor Bailliere, Tindall and Cassell, London. $22-42$.

Huff, M.E., W.E. Balch, and J.W. Kelly. 2003. Pathological and functional amyloid formation orchestrated by the secretory pathway. Current Opinion in Structural Biology 13:674-682.

Jensen, P. 2006. Domestication -From behaviour to genes and back again. Applied animal behaviour science 97:3-15.

Jones, R.B., H.J. Blokhuis, and G. Beuving. 1995. Open-field and tonic immobility responses in domestic chicks of two genetic lines differing in their propensity to feather peck. British Poultry Science 36:525-530.

Jung Hun, O., H. Sun Kyoung, P. Do Joon, P. Kyong Soo, and P. Young Joo. 2013. Expression of Thyroid Stimulating Hormone Receptor mRNA in Mouse C2C12 Skeletal Muscle Cells. Endocrinology \& Metabolism 28:119.

Karlsson, A.-C., P. Mormede, S. Kerje, and P. Jensen. 2011. Genotype on the Pigmentation Regulating PMEL17 Gene Affects Behaviour in Chickens Raised Without Physical Contact with Conspecifics. Behaviour Genetics 41:312-322.

Karlsson, A.C., S. Kerje, L. Andersson, and P. Jensen. 2010. Genotype at the PMEL17 locus affects social and explorative behaviour in chickens. British Poultry Science 51:170-177.

Keeler, C., and L. Moore. 1961. Psychosomatic synthesis of behaior trends in the taming of mink. Bulletin of the Georgia Academy of Science 19:66-74. 
Keeling, L., L. Andersson, K.E. Schutz, S. Kerje, R. Fredriksson, O. Carlborg, C.K. Cornwallis, T. Pizzari, and P. Jensen. 2004a. Chicken genomics: Featherpecking and victim pigmentation. Nature 431:645-646.

Keeling, L., L. Andersson, K.E. Schütz, S. Kerje, R. Fredriksson, Ö. Carlborg, C.K. Cornwallis, T. Pizzari, and P. Jensen. 2004b. Feather-pecking and victim pigmentation. Nature 431:645-646.

Kerje, S., O. Carlborg, L. Jacobsson, K. Schutz, C. Hartmann, P. Jensen, and L. Andersson. 2003. The twofold difference in adult size between the red junglefowl and White Leghorn chickens is largely explained by a limited number of QTLs. Anim Genet 34:264-274.

Kerje, S., P. Sharma, U. Gunnarsson, H. Kim, S. Bagchi, R. Fredriksson, K.E. Schütz, P. Jensen, G. von Heijne, R. Okimoto, and L. Andersson. 2004. The Dominant white, Dun and Smoky color variants in chicken are associated with insertion/deletion polymorphisms in the PMEL17 gene. Genetics 168:15071518.

Kjaer, J.B., and D. Guémené. 2009. Adrenal reactivity in lines of domestic fowl selected on feather pecking behaviour. Physiology \& Behaviour 96:370-373.

Korte, S.M., G. Beuving, W. Ruesink, and H.J. Blokhuis. 1997. Plasma catecholamine and corticosterone levels during manual restraint in chicks from a high and low feather pecking line of laying hens. Physiology and Behaviour 62:437-441.

Kuehn, F.S., and M.P. Lozada. 2009. Thyroid hormones [Elektronisk resurs] : functions, related diseases and uses / Francis S. Kuehn and Mauris P. Lozada, editors. New York : Nova Biomedical Books, c2009.,

Lindley, S.E., K.J. Lookingland, and K.E. Moore. 1990. Dopaminergic and betaadrenergic receptor control of alpha-melanocyte-stimulating hormone secretion during stress. Neuroendocrinology 52:46-51.

Lindqvist, C., A.M. Janczak, D. Nätt, I. Baranowska, N. Lindqvist, A. Wichman, J. Lundeberg, J. Lindberg, P.A. Torjesen, and P. Jensen. 2007. Transmission of stress-induced learning impairment and associated brain gene expression from parents to offspring in chickens. PLoS one 1-7.

Lindqvist, C.E.S., K.E. Schütz, and P. Jensen. 2002. Red jungle fowl have more contrafreeloading than white leghorn layers: effect of food deprivation and consequences for information gain. Behaviour 139:1195-1209.

Lobo, I. 2008a. Pleiotropy: One gene can affect multiple traits. Nature Education 1:

Lobo, I.S., K. 2008b. Discovery and types of genetic linkage. Nature Education 1:

Miles, C.W., M. 2008. Quantitative trait locus (QTL) analysis. Nature Education $1: 208$.

Ming, M., X. Li, X. Fan, D. Yang, L. Li, W. Le, S. Chen, and Q. Gu. 2009. Retinal pigment epithelial cells secrete neurotrophic factors and synthesize dopamine: Possible contribution to therapeutic effects of RPE cell transplantation in Parkinson's disease. Journal of Translational Medicine 7:

Nakao, N., H. Ono, T. Yamamura, T. Anraku, T. Takagi, K. Higashi, S. Yasuo, Y. Katou, S. Kageyama, Y. Uno, T. Kasukawa, M. Iigo, P.J. Sharp, A. Iwasawa, Y. Suzuki, S. Sugano, T. Niimi, M. Mizutani, T. Namikawa, and S. Ebihara. 2008. Thyrotrophin in the pars tuberalis triggers photoperiodic response. Nature 452:317-322. 
Nielsen, R., S. Williamson, Y. Kim, M.J. Hubisz, A.G. Clark, and C. Bustamante. 2005. Genomic scans for selective sweeps using SNP data. Genome Research 15:1566-1575.

Nätt, D., S. Kerje, L. Andersson, and P. Jensen. 2007. Plumage color and feather pecking-behavioural differences associated with PMEL17 genotypes in chicken (Gallus gallus). Behaviour Genetics 37:399-407.

Price, E.O. 1984. Behavioural Aspects of Animal Domestication. Quarterly Review of Biology 59:1-32.

Price, E.O. 1998. Behavioural genetics and the process of animal domestication. In Genetics and the behaviour of domestic animals. T. Grandin, editor Academic press, 31-65.

Price, E.O. 1999. Behavioural development in animals undergoing domestication. Applied Animal Behaviour Science 65:245-271.

Ramsey, D.T., S.L. Ewart, J.A. Render, C.S. Cook, and C.A. Latimer. 1999. Congenital ocular abnormalities of rocky mountain horses. Veterinary Ophthalmology 2:47-59.

Raposo, G., D. Tenza, D.M. Murphy, J.F. Berson, and M.S. Marks. 2001. Distinct Protein Sorting and Localization to Premelanosomes, Melanosomes, and Lysosomes in Pigmented Melanocytic Cells \{image\}. J. Cell Biol. 152:809-824.

Riedstra, B., and T.G.G. Groothuis. 2002. Early feather pecking as a form of social exploration: The effect of group stability on feather pecking and tonic immobility in domestic chicks. Applied Animal Behaviour Science 77:127-138.

Rindos, D. 1980. Symbiosis, Instability, and the Origins and Spread of Agriculture: A New Model. Current Anthropology 21:751-772.

Rodenburg, T.B., and P. Koene. 2003. Comparison of individual and social feather pecking tests in two lines of laying hens at ten different ages. Applied Animal Behaviour Science 81:133-148.

Rubin, C.-J., M.C. Zody, J. Eriksson, J.R.S. Meadows, E. Sherwood, M.T. Webster, J. Lin, M. Ingman, T. Sharpe, K. Sojeong, F. Hallböök, F. Besnier, Ö. Carlborg, B. Bed'hom, M. Tixier-Boichard, P. Jensen, P. Siegel, K. Lindblad-Toh, and L. Andersson. 2010. Whole-genome resequencing reveals loci under selection during chicken domestication. Nature 464:587-591.

Savory, C.J., and J.S. Mann. 1999. Feather pecking in groups of growing bantams in relation to floor substrate and plumage colour. British Poultry Science 40:565572.

Schonthaler, H.B., J.M. Lampert, J. von Lintig, H. Schwarz, R. Geisler, and S.C.F. Neuhauss. 2005. A mutation in the silver gene leads to defects in melanosome biogenesis and alterations in the visual system in the zebrafish mutant fading vision. Developmental Biology 284:421-436.

Schütz, K.E. 2002. Trade-off in resource allocation between behaviour and production in fowl-phenotypic studies and qtl-analyses in red junglefowl, white leghorn and their f2-progeny. In Swedish University of Agricultural Sciences, Skara. 
Schütz, K.E., B. Forkman, and P. Jensen. 2001. Domestication effects on foraging strategy, social behaviour and different fear responses: a comparison between the red junglefowl (Gallus gallus) and a modern layer strain. Applied Animal Behaviour Science 74:1-14.

Schütz, K.E., and P. Jensen. 2001. Effects of Resource Allocation on Behavioural Strategies: A Comparison of Red Junglefowl (Gallus gallus) and Two Domesticated Breeds of Poultry. Ethology 107:753-765.

Setchell, B.P. Domestication and reproduction. Animal Reproduction Science 28:195202.

Siegel, P.B., A. Haberfeld, T.K. Mukherjee, L.C. Stallard, H.L. Marks, N.B. Anthony, and E.A. Dunnington. 1992. Jungle fowl-domestic fowl relationships: a use of DNA fingerprinting. World's Poultry Science Journal 48:147-155.

Sulzer, D., J. Bogulavsky, K.E. Larsen, G. Behr, E. Karatekin, M.H. Kleinman, N. Turro, D. Krantz, R.H. Edwards, L.A. Greene, and L. Zecca. 2000. Neuromelanin Biosynthesis Is Driven by Excess Cytosolic Catecholamines Not Accumulated by Synaptic Vesicles. In National Academy of Sciences of the United States of America, 11869.

Theos, A.C., S.T. Truschel, G. Raposo, and M.S. Marks. 2005. The Silver locus product Pmel17/gp100/Silv/ME20: controversial in name and in function. Pigment Cell Research 18:322-336.

Trapezov, O., L. Trapezova, and E. Sergeev. 2008. Effect of coat color mutations on behavioural polymorphism in farm populations of American minks ( Mustela vison Schreber, 1777) and sables ( Martes zibellina Linnaeus, 1758). Russian Journal of Genetics 44:444-450.

Trut, L., I. Oskina, and A. Kharlamova. 2009. Animal evolution during domestication: the domesticated fox as a model. BioEssays 31:349-360.

Trut, L.N. 1999. Early canid domestication: the farm-fox experiment. American Scientist 87:160-169.

West, B., and B.X. Zhou. 1988. Did chickens go North? New evidence for domestication. Journal of Archaeological Science 15:515-533.

Vestergaard, K.S., J.P. Kruijt, and J.A. Hogan. 1993. Feather pecking and chronic fear in groups of red junglefowl: Their relations to dustbathing, rearing environment and social status. Animal Behaviour 45:1127-1140.

Yasumoto, K.-i., H. Watabe, J.C. Valencia, T. Kushimoto, T. Kobayashi, E. Appella, and V.J. Hearing. 2004. Epitope mapping of the melanosomal matrix protein gp100 (PMEL17). The Journal of Biological Chemistry 279:28330-28338.

Yasuo, S., M. Watanabe, N. Nakao, T. Takagi, S. Ebihara, T. Yoshimura, and B.K. Follett. 2005. The reciprocal switching of two thyroid hormone-activating and inactivating enzyme genes is involved in the photoperiodic gonadal response of Japanese Quail. Endocrinology 146:2551-2554.

Yoshimura, T. 2013. Thyroid hormone and seasonal regulation of reproduction. Frontiers in Neuroendocrinology 34:157-166.

Zhang, W., L.M. Tian, Y.Y. Han, J. Guo, L. Gao, J.J. Zhao, H.Y. Ma, and L.C. Wang. 2009. Presence of thyrotropin receptor in hepatocytes: Not a case of illegitimate transcription. Journal of Cellular and Molecular Medicine 13:4636-4642. 


\section{Papers}

The articles associated with this thesis have been removed for copyright reasons. For more details about these see:

http://urn.kb.se/resolve?urn=urn:nbn:se:liu:diva-112870 